\title{
KNOWLEDGE, ATTITUDE AND PRACTICE OF COMMUNITY PHARMACY PERSONNEL ABOUT IMPLEMENTATION OF THE PHARMACEUTICAL TRACK AND TRACE SYSTEM, IN TURKEY
}

\author{
ÖZLEM NAZAN ERDOĞAN ${ }^{1}$, ÖZLEM AKBAL DAĞISTAN ${ }^{2} *$, MIRAY ARSLAN ${ }^{3}$, GÜLNAZ \\ ÇIĞ $^{4}$, ALI SAYAR ${ }^{5}$, MEHMET SARPER ERDOGAN ${ }^{6}$
}

${ }^{I}$ Department of Pharmacy Management, Faculty of Pharmacy, Istanbul University, Istanbul, Turkey

${ }^{2}$ Department of Pharmaceutical Technology, Faculty of Pharmacy, Istanbul University, Istanbul, Turkey

${ }^{3}$ Department of Pharmacy Management, Faculty of Pharmacy, Van Yuzuncu Yll University, Van, Turkey

${ }^{4}$ Tuberculosis Unit, Erzurum Yakutiye District Health Directorate, Erzurum, Turkey

${ }^{5}$ Faculty of Pharmacy, Istanbul, Turkey

${ }^{6}$ Department of Public Health, Cerrahpasa Medical Faculty, Istanbul University-Cerrahpasa, Istanbul, Turkey

*corresponding author: ozlemakbal@istanbul.edu.tr

Manuscript received: April 2020

\begin{abstract}
Pharmaceutical Track and Trace System (PTTS) is a successful implementation of Track and Trace approach which has been applied since 2010 in Turkey. Briefly, it defines the infrastructure framework for all units belonging to each product and works by using the Datamatrix code, which provides the sureness of the uniqueness. The aim of this study was to evaluate the community pharmacy personnel's attitudes and knowledge about the PTTS, in order to reveal their expectations and identify problems thereof. 56 community pharmacies located in Beyoglu district of Istanbul, Turkey $(\mathrm{n}=120)$ were included. The data were collected from $15^{\text {th }}-30^{\text {th }}$ of April 2017 by a structured questionnaire. Besides evaluating descriptive statistics, $\chi^{2}$ test was conducted to analyse relationship between demographics and knowledge, attitudes, and practices of the pharmacy personnel, respectively. This study shows that PTTS is found useful especially for providing drug safety and facilitating and accelerating the recall of the drugs.
\end{abstract}

\section{Rezumat}

Sistemul de monitorizare a medicamentelor (SMM) reprezintă implementarea cu succes a abordării trasabilităţii acestora din activitatea practică în Turcia încă din anul 2010. Pe scurt, definește cadrul de infrastructură pentru fiecare medicament și codul Datamatrix, care asigură unicitatea produsului. Scopul acestui studiu a fost de a evalua atitudinile și cunoștințele personalului farmaciei comunitare despre SMM, aşteptările acestora şi de a identifica problemele cu care se confruntă. În acest studiu au fost incluse 56 de farmacii comunitare situate în districtul Beyoglu din Istanbul, Turcia $(\mathrm{n}=120)$. 56 de farmacii au participat la studiu. Datele au fost colectate în perioada 15 - 30 aprilie 2017 printr-un chestionar structurat. Pe lângă evaluarea statistică descriptivă, testul $\chi^{2}$ a fost realizat pentru a analiza relația dintre aspectul demografic și cel științific, corelat cu atitudinea și practicile personalului din farmacie.

Keywords: pharmacy practice; pharmaceutical track and trace system, safety

\section{Introduction}

Contemporary progress in science and technology is an important factor in designation of the countries' prosperity. At the same time, this progress arises as a power which seriously contributes to the economy and socio-cultural structure of these countries. This progress has a role not only in designation of state policies, but also in development of healthcare, which is a priority area for countries.

In this context, patients' attainment of true and genuine medicine, which is the primary source for protecting and/or regaining health, is a keystone for the health policies. Although there are different definitions for counterfeit drugs in the literature, National Authorities mainly accept the World Health
Organization's (WHO) latest definition in which WHO classifies counterfeit medicines and defines them as (1) substandard (authorized medicinal products that fail to meet either their quality standards or specifications, or both), (2) unregistered (that have not undergone approval by the National or Regional Authority for the market in which they are distributed), and (3) falsified (that deliberately misrepresent their identity, composition or source) medicinal products $[1,2]$.

Based on WHO's latest statistical analysis report, it is estimated that up to $15 \%$ of medicinal products sold in the worldwide are classified as counterfeit drugs and this ratio is higher for the developing countries and goes up to $30 \%$ [3]. Another source of counterfeit drugs is the internet, as many pharmaceuticals 
are sometimes sold online. It is known that the internet based sold medicines are 50\% illegal and counterfeit. In addition, purchasing via internet (or internet shopping) is mainly attractive for elderly and disabled due to its quickness and convenience. Also, purchasing via internet is cheaper for Over the Counter (OTC) products in general [4].

There are app. 30,000 - 35,000 online pharmacies operating globally, and $96 \%$ of them are serving illegitimately [5]. In 2014, the global online pharmacy market was estimated to be worth approx. 29 billion U.S. dollars. By 2023, it is predicted that the market will grow to reach around 128 billion dollars [6].

Counterfeiting provides extreme profit to the traffickers. An example given in a study report published by International Institute of Research Against Counterfeit Medicines (IRACM, 2013), showed the estimated value of the profit clearer, for incidence; a $\$ 1000$ investment on to the trafficking of counterfeiting currency or of heroin gets a return of $\$ 20,000$, of counterfeit tobacco $\$ 43,000$; in case of counterfeit medication, the return would be between $\$ 200,000$ and 450,000 regarding the type of medicine and country [7]. In addition to the fake manufacturing, drug traffickers are also seeking ways to infiltrate into the legal distribution chain. For this purpose, they are trying to steal approved shipments and redirect them through the new markets to earn profits [8]. Another way to break into the legal supply chain is "the perfect storm time" like the influenza season for flu medications, when legal supplier of a medicinal drug, is unable to supply the high market demand and, therefore, product shortages appear, pharmacists seeking alternative suppliers, drug traffickers become the supplier that meets the market need [9]. Other serious and rising threat related to drug packaging is the "third shift" packaging production, in which contractors or their workers manufacture extra hidden packaging and selling these originals to the counterfeiters [8].

The fake medicine report written-up by the European Union Intellectual Property Office (EUIPO), indicates that fake medicines have a cost to the European pharmacy sector 10.2 billion Euro/year, almost $4.4 \%$ of sales [10].

Therefore, the countries have started to take some precautions against the counterfeit drugs, which create serious health risks, as well as important social and economic damage.

Supply chain product visibility can be defined as "the content of the supply chain to provide general information about the product life cycle, which is starting from the formulation step for pharmaceuticals and followed by production, distribution, reaching to the end-user, user feedback, and lastly product endof-life activities" [11]. This whole system relies on developing and keeping the record of these related activity to promote planning and control the product and related operations to improve end-user experience of the product [11]. As many industrial sectors like aviation, transportation, healthcare in terms of pharmaceutical producers, uses end-to-end supply chain product visibility by product tracking and tracing [12], product tracking is mainly used to describe the identity and product state of art from the production to the end user. On the other hand, tracing used to ascertain the origin, design, and composition etc. of the product from downstream to upstream to the supply chain. These two main elements, tracking and tracing are complementary activities that are mainly used to increase the security level of the product [11]. Autoidentification systems are enabling far reaching opportunities as supply chain management tools. Auto ID systems like barcode, Radio Frequency Identity (RIFD) and sensor systems are in use in pharmaceutical field supply chain system for years.

In the United States, the US FDA (Food and Drug Administration) implemented rule 21 CFR part 211, in which current good manufacturing practices (cGMP) are specified for finished medicinal products. In the related framework, tamper evident packaging is mandatory for the over the counter drugs for human use. And the regulation also protects the counterfeit via both hindering the selling of production material, and using the commonly available materials and process for packaging (FDA, 2011).

In 2011, the European Union published a directive (2011/62/EU) for the prevention of counterfeit medicine from the legal supply chain and pointed out that each drug is unique. Therefore, a unique identification should be put on each box of the drug (EU 2011). The latest delegated Regulation 161/2016/EU was put into practice from the 9th of February 2019, in which, besides serialization requirements, anti-tampering devices for drug packaging are demanded. Also, counterfeiting of the enclosed medicinal product should be prevented. In 2016, European Commission, demanded from manufacturers who distribute their medicinal products, to designate prescription drugs with a unique serial code that can be transfer related information to the Europe-wide database and is covered with tightest security conditions. The related security code will be specified by the EU and the two dimensional (2D) data matrix code will provide traceability of the product for the entire supply chain and become a vital part of the product life cycle [1]. In July 2010, Turkish Ministry of Health adopted Track and Trace system into pharmaceutical industry in order to prevent drugs fraud, counterfeit and smuggling of the drugs and started the Turkey's serialization scheme (ITS) before the European Union [13]. This scheme is regulated under the law "Regulation Regarding the Packaging and Labelling of Medicinal Products for Human Use". The Turkish Ministry of Health $(\mathrm{MOH})$ requires serializing and tracing the product using 2D Data Matrix technology for all unit 
level items that are reimbursed by $\mathrm{MOH}$ and the system covers the prescription, non-prescriptions drugs and medical nutrition products including promotional samples and hospital packaged products. On the other hand, it does not cover the magisterial drugs and radiopharmaceutical products [13].

In this regard, the aim of the present study was to evaluate knowledge, attitude and practices of community pharmacy staff about the implementation of the Turkish PTTS in order to reveal their expectations and identify their problems about the system. The motivation of the study comes from the lack of a study on this subject, although this system has been used since 2010 in Turkey.

\section{Materials and Methods}

\section{Study Design and Setting}

The study was a qualitative cross-sectional study. A survey was carried out in order to evaluate the knowledge, attitude and practices of the community pharmacy personnel about implementation of the drug tracking system in Istanbul, Turkey. Community pharmacies located in Beyoglu district of Istanbul were included into the study $(\mathrm{n}=120) .56$ pharmacies participated in the study. The data were collected from $15^{\text {th }}-30^{\text {th }}$ of April 2017.

Study Instrument and Sampling Procedure

The study contained a 25 points pre-designed questionnaire. Previous studies conducted on knowledge, attitude, practice of healthcare professionals was utilized while preparing the questionnaire [14].

The personnel were voluntarily conducted in the study by the permission of the Istanbul Chamber of Pharmacy. A brief explanatory speech delivered to volunteers one to one, and then verbal consent from the volunteers was obtained. The questionnaire was administered face to face and retrieved on completion on the same day.

\section{Research Hypotheses}

In the study, the effects of the demographics of the participants on the knowledge, attitudes, and practices were investigated; accordingly, the main hypotheses of the study were conducted as following: $\mathrm{H}_{1 \mathrm{a}}$ : There is a relationship between the gender of the participants and their knowledge about Turkish PTTS; $\mathrm{H}_{1 \mathrm{~b}}$ : There is a relationship between the education level of the participants and their knowledge about Turkish PTTS; $\mathrm{H}_{1 \mathrm{c}}$ : There is a relationship between the working year of the participants as community pharmacy personnel and their knowledge about Turkish PTTS; $\mathrm{H}_{2 \mathrm{a}}$ : There is a relationship between the gender of the participants and their attitude toward Turkish PTTS; $\mathrm{H}_{2 \mathrm{~b}}$ : There is a relationship between the education level of the participants and their attitude toward Turkish PTTS; $\mathrm{H}_{2 \mathrm{c}}$ : There is a relationship between the working year of the participants as community pharmacy personnel and their attitude toward Turkish PTTS; $\mathrm{H}_{3 \mathrm{a}}$ : There is a relationship between the gender of the participants and their practices with Turkish PTTS; $\mathrm{H}_{3 \mathrm{~b}}$ : There is a relationship between the education level of the participants and their practices with Turkish PTTS; $\mathrm{H}_{3 \mathrm{c}}$ : There is a relationship between the working year of the participants as community pharmacy personnel and their practices with Turkish PTTS.

In addition, relationships between knowledge, attitude and practice of the community pharmacy personnel about Turkish PTTS were evaluated according to following hypotheses: $\mathrm{H}_{4}$ : There is a relationship between knowledge and attitude of the community pharmacy personnel about Turkish PTTS; $\mathrm{H}_{5}$ : There is a relationship between knowledge and practice of the community pharmacy personnel about Turkish PTTS; $\mathrm{H}_{6}$ : There is a relationship between attitude and practice of the community pharmacy personnel about Turkish PTTS.

Statistical Analysis

Collected data were analysed via IBM Statistical Package for Social Sciences (IBM SPSS ${ }^{\circledR}$ Software) version 22 (SPSS, Inc. Chicago, IL, USA). Firstly, descriptive statistics were given and Chi-Square test was performed. The level of significance was set a priori at $\mathrm{p} \leq 0.05$.

\section{Results and Discussion}

Results on demographics of the respondent pharmacy personnel

Basic demographics of respondent pharmacy personnel are presented in Table I.

Table I

Demographics of the respondent pharmacy personnel

\begin{tabular}{|c|c|}
\hline Gender & $\begin{array}{c}\text { All Respondents } \\
\mathrm{n}(\%)\end{array}$ \\
\hline Female & \\
\hline Male & $19(33.93)$ \\
\hline Education level & $37(66.07)$ \\
\hline University-Post Graduate & $14(25.0)$ \\
\hline High School & $30(53.6)$ \\
\hline Primary School & $12(21.4)$ \\
\hline Years of Practice (or working years) & \\
\hline 0 - 10 years & $22(39.3)$ \\
\hline 10 - 20 years & $18(32.1)$ \\
\hline$>$ 20 years & $16(28.6)$ \\
\hline
\end{tabular}

From the 120 copies of the questionnaire administered, 56 were properly completed and evaluated within the study. In other words, $47 \%$ participation rate was reached.

As seen from Table I, the majority of the participants were male $(66 \%)$. The average age of the participants was 35.5 also the minimum age was 20 and maximum 68 years old. When the education level had been evaluated, it was seen that only $25 \%$ of them graduated from university. The percentages of the pharmacy 
FARMACIA, 2021, Vol. 69, 2

personnel with more than ten years' experience was $64.29 \%$ and only $3.57 \%$ of them had a job practice other than in pharmacy.

Results on knowledge of pharmacy personnel about pharmaceutical track and trace system

All participants were aware of the term of Pharmaceutical Track and Trace System even though only $16.07 \%$ of them attended any kind of seminar or training related to Pharmaceutical Track and Trace System. Similarly,
$71.43 \%$ of them think that there was not made sufficient educative study over the Pharmaceutical Track and Trace System (Table II).

Chi-Square test was conducted to analyse relationship between demographics (gender, education level, and working years) and attending any kind of seminar or training related to PTTS. The results are depicted in Table III.

Table II

Knowledge of Pharmacy Personnel to Pharmaceutical Track and Trace System

\begin{tabular}{|l|c|c|}
\hline \multicolumn{1}{|c|}{ Variable } & \multicolumn{2}{c|}{ All Respondents, n (\%) } \\
\hline & Yes & No \\
\hline Attended any kind of seminar or training related to PTTS & $9(16.07)$ & $47(83.93)$ \\
\hline Adequate educative study & $16(28.57)$ & $40(71.43)$ \\
\hline
\end{tabular}

Table III

The results of the Chi-Square test for expressing the relationship between demographics (gender, education level and working years) and attending any kind of seminar or training related to PTTS

\begin{tabular}{|c|c|c|c|}
\hline & & \multicolumn{2}{|c|}{ Attended any kind of seminar or training related to PTTS } \\
\hline & & Yes & No \\
\hline \multirow{2}{*}{ Gender } & Male & 6 & 31 \\
\hline & Female & 3 & 16 \\
\hline \multicolumn{4}{|c|}{$\chi^{2}=0.002$} \\
\hline \multirow{3}{*}{ Education level } & University-Post Graduate & 3 & 11 \\
\hline & High School & 4 & 26 \\
\hline & Primary School & 2 & 10 \\
\hline \multicolumn{4}{|c|}{$\chi^{2}=0.468$} \\
\hline \multirow{3}{*}{ Working years } & $0-10$ years & 4 & 18 \\
\hline & $11-20$ years & 3 & 15 \\
\hline & $>20$ years & 2 & 14 \\
\hline \multicolumn{4}{|c|}{$\chi^{2}=0.229, \quad p=0.892$} \\
\hline
\end{tabular}

As seen in Table III, there was not established any relationship between gender groups and attending any kind of seminar or training related to PTTS and similarly, any relationship between working years of the participants and attending any kind of seminar or training related to PTTS. In this regard, $\mathrm{H}_{1 \mathrm{a}}, \mathrm{H}_{1 \mathrm{~b}}$ and $\mathrm{H}_{1 \mathrm{c}}$ were rejected.
Results on attitude of Pharmacy Personnel toward Pharmaceutical Track and Trace System

In this section, attitude of pharmacy personnel towards pharmaceutical track and trace system were evaluated in terms of drug safety, information technology (IT) and shareholders liability.

Attitude of Pharmacy Personnel Aspect of Drug Safety via Pharmaceutical Track and Trace System

\begin{tabular}{|c|c|c|}
\hline \multicolumn{1}{|c|}{ Variable } & All Respondents, $\mathrm{n}(\%)$ \\
\hline & Yes & No \\
\hline Drug Safety & & \\
\hline Contribution to the drug safety & $49(87.5)$ & $7(12.5)$ \\
\hline 1. To provide determination of drugs country of origin and drugs movements & $38(67.86)$ & $18(32.14)$ \\
\hline 2. Hindering selling the same drug second time & $32(57.14)$ & $24(42.86)$ \\
\hline 3. Hindering selling the sell-by-date drugs & $27(48.21)$ & $29(51.79)$ \\
\hline 4. Hindering releasing of the counterfeit drugs and nonconforming drugs to the market & $23(41.07)$ & $33(58.93)$ \\
\hline Increasing accessibility of the drugs & $31(55.36)$ & $25(44.64)$ \\
\hline Facilitate and accelerate recall of the drugs & $40(71.43)$ & $16(28.57)$ \\
\hline Increase product availability of the drugs in the market & $21(37.50)$ & $35(62.50)$ \\
\hline Consider that acquired statistical data and product location data, used sufficiently true enough & $32(57.14)$ & $24(42.86)$ \\
\hline
\end{tabular}

Results on attitude of Pharmacy Personnel Aspect to Drug Safety

In the majority of the responders $(87.5 \%)$, the pharmaceutical track and trace system makes its' contribution to the drug safety. Similarly, $71.43 \%$ consider that the system facilitates and accelerate recall of the drugs. Only $55.36 \%$ of personnel agreed that system increase drugs accessibility and merely 
$37.5 \%$ of the personnel thought that system increase product availability of the drugs in the market (Table IV). Chi-Square test was conducted to analyse relationship between demographics (gender, education level and working years) and "contribution to the drug safety" The results were given in Table V.

Table $\mathrm{V}$ shows that there was not established any relationship between demographics (gender, education level and working years) of the participants and "Contribution to the drug safety". Similarly, any statistically significant relationship between demographics and "Increase product availability of the drugs in the market", and "Consider that acquired statistical data and product location data, used sufficiently true enough", respectively, were not found. On the other hand, as it can be seen from Table VI, there were statistically significant relationships between gender and working years of the participants and "Facilitate and accelerate recall of the drugs".

Table V

The results of the Chi-Square test for relationship between demographics (gender, education level, and working years) and "Contribution to the drug safety"

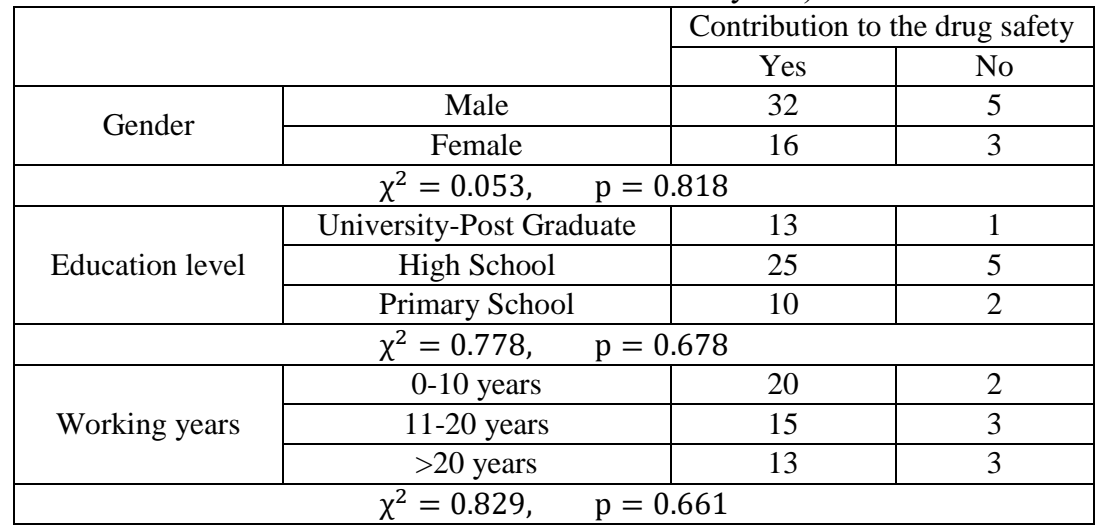

Table VI

The results of the Chi-Square test for relationship between demographics (gender, education level, and working years) and "Contribution to the drug safety"

\begin{tabular}{|c|c|c|c|}
\hline & \multicolumn{2}{|c|}{ Contribution to the drug safety } \\
\hline & & Yes & No \\
\hline \multirow[t]{2}{*}{ Gender } & Male & 30 & 7 \\
\hline & Female & 10 & 9 \\
\hline \multicolumn{4}{|c|}{$\chi^{2}=4.979, p=0.026^{*}$} \\
\hline \multirow{3}{*}{ Working years } & $0-10$ years & 19 & 3 \\
\hline & $11-20$ years & 9 & 9 \\
\hline & $>20$ years & 12 & 4 \\
\hline \multicolumn{4}{|c|}{$\chi^{2}=6.555, \mathrm{p}=0.038^{*}$} \\
\hline
\end{tabular}

Results on attitude of Pharmacy Personnel Aspect to IT

As it can be seen from Table VII, the major consideration for satisfaction from the performance of the Pharmaceutical Track and Trace system is high (80.00\%), and considering that the system could respond their needs $(98.21 \%)$, system has sufficient information to operate properly and agreed that the system is handy $(96.43 \%)$ to use. Additionally, more than half of the responders (64.29\%) think that the system contributes operating expenses of the pharmacy. However almost all responders found data input $(91.07 \%)$ and server capacity $(89.29 \%)$ inadequate, and on the contrary, they agreed that system has adequate visuality. Besides, only $25.00 \%$ of responders found frequent disconnection problems and only $23.21 \%$ responders found existing internet infrastructure operating system insufficient, $64.29 \%$ of responders faced system failure at least once in a day time running and $26.79 \%$ faced system based failure more than five in a day time running.

Chi-Square test was conducted to analyse relationship between demographics (gender, education level and working years) and "Satisfaction from Pharmaceutical Track and Trace Systems' Performance". As a result, there was not found any statistically significant relationship between demographics (gender, education level and working years) of the participants and "Satisfaction from Pharmaceutical Track and Trace Systems' Performance". 
Table VII

Attitude of Pharmacy Personnel Aspect of IT via Pharmaceutical Track and Trace System

\begin{tabular}{|l|c|c|}
\hline \multicolumn{1}{|c|}{ Variable } & \multicolumn{2}{c|}{ All Respondents, $\mathrm{n}(\%)$} \\
\hline \multicolumn{2}{|c|}{ Yes } & \multicolumn{2}{c|}{ No } \\
\hline IT & & \\
\hline Satisfaction from Pharmaceutical Track and Trace Systems' Performance & $44(80.00)$ & $11(20.00)$ \\
\hline $1 . \quad$ Inadequate data input & $51(91.07)$ & $5(8.93)$ \\
\hline $2 . \quad$ Inadequate server capacity & $50(89.29)$ & $6(10.71)$ \\
\hline $3 . \quad$ Frequently disconnection problems & $14(25.00)$ & $42(75.00)$ \\
\hline $4 . \quad$ Insufficiency of existing internet infrastructure operating system properly & $13(23.21)$ & $43(76.79)$ \\
\hline $5 . \quad$ Inadequate visuality & $4(7.14)$ & $52(92.86)$ \\
\hline $6 . \quad$ Insufficient information & $4(7.14)$ & $52(92.86)$ \\
\hline $7 . \quad$ Impractical system & $2(3.57)$ & $54(96.43)$ \\
\hline $8 . \quad$ Could not respond need & $1(1.79)$ & $55(98.21)$ \\
\hline $\begin{array}{l}\text { Considering that Pharmaceutical Track and Trace System contribute operating expenses of the } \\
\text { pharmacy }\end{array}$ & $36(64.29)$ & $20(35.71)$ \\
\hline
\end{tabular}

Results on attitude of Pharmacy Personnel Aspect to Shareholders Liability

The highest part of responders thought that pharmaceutical manufacturers and pharmaceutical warehouses did not work well enough for Pharmaceutical Track and Trace System to function properly (Table VIII).

Chi-Square test was conducted to analyse relationship between demographics (gender, education level and working years) and "Think that pharmaceutical manufacturers and pharmaceutical warehouses work well enough for Pharmaceutical Track and Trace System to function properly?". As a result, there was not found any statistically significant relationship between demographics (gender, education level and working years) of the participants and "Think that pharmaceutical manufacturers and pharmaceutical warehouses work well enough for Pharmaceutical Track and Trace System to function properly?".

In this regard, it is possible to say that $\mathrm{H}_{2 \mathrm{a}}, \mathrm{H}_{2 \mathrm{~b}}$ and $\mathrm{H}_{2 \mathrm{c}}$ were rejected.

Table VIII

Attitude of Pharmacy Personnel Aspect of Shareholder Liability via Pharmaceutical Track and Trace System

\begin{tabular}{|r|c|c|}
\hline \multicolumn{1}{|c|}{ Variable } & \multicolumn{2}{|c|}{ All Respondents, $\mathrm{n}(\%)$} \\
\hline \multicolumn{1}{|c|}{ Yes } & No \\
\hline $\begin{array}{r}\text { Think that pharmaceutical manufacturers and pharmaceutical warehouses work well enough } \\
\text { for Pharmaceutical Track and Trace System to function properly? }\end{array}$ & $24(42.86)$ & $31(55.36)$ \\
\hline $1 . \quad$ Redesign the pharmaceutical drug packaging so that the system function properly & $5(23.81)$ & $16(76.19)$ \\
\hline $2 . \quad$ Improve existing systems & $5(21.74)$ & $18(78.26)$ \\
\hline $3 . \quad$ Establish a call center to solve system related problems & $4(12.50)$ & $28(87.50)$ \\
\hline
\end{tabular}

Furthermore, Chi-Square test was conducted for evaluating relationship between knowledge and attitude of the community pharmacy personnel about Turkish PTTS. For this aim, relationship between "Attended any kind of seminar or training" and attitude questions were evaluated. As a result of the analyse, there is not found any statistically significant relationship between them. Therefore, the fourth hypothesis of the study was rejected.
Results on practice of Pharmaceutical Track and Trace System by Pharmacy Personnel

In the study, practice of the Turkish PTTS was evaluated under two main topic such as stock management and solutions performed when the system not work. Regarding to the stock management questions (Table IX), more than half of the responders $(57.14 \%)$ faced circumstances undermatch their stock records and the pharmacy management programmes used in the pharmacy $(32.60 \%)$, and lack of data entry by relevant personnel $(30.43 \%)$ encountered as the main reasons respectively.

Table IX

Practice of Pharmaceutical Track and Trace System by Pharmacy Personnel

\begin{tabular}{|c|c|c|}
\hline \multicolumn{1}{|c|}{ Variable } & \multicolumn{2}{c|}{$\begin{array}{c}\text { All Respondents } \\
\mathrm{n}(\%)\end{array}$} \\
\hline \multicolumn{1}{|c|}{ Stock Management } & $32(57.14)$ & $24(42.86)$ \\
\hline Confront circumstances undermatch own stock records & $51(91.07)$ & $5(8.93)$ \\
\hline $1 . \quad$ Used pharmacy programme generated fault & $43(76.79)$ & $13(23.21)$ \\
\hline $2 . \quad$ Insufficiency of existing internet infrastructure generated fault & $43(76.79)$ & $13(23.21)$ \\
\hline 3. Lack of data entry by relevant personnel & $39(69.64)$ & $17(30.36)$ \\
\hline 4. $\quad$ Pharmaceutical Track and Trace system generated fault &
\end{tabular}


FARMACIA, 2021, Vol. 69, 2

Regarding the question about solutions performed when the system not work (Table X) furthermore, relationship between demographics (gender, education level and working years) and "Solutions those personnel perform, when track and trace system or social security institutions' system not work" were analysed via ChiSquare test and the results are presented in Table X.

Table X

The results of the Chi-Square test for relationship between demographics (gender and working years) and "Solutions those personnel perform, when track and trace system or social security institutions' system not work"

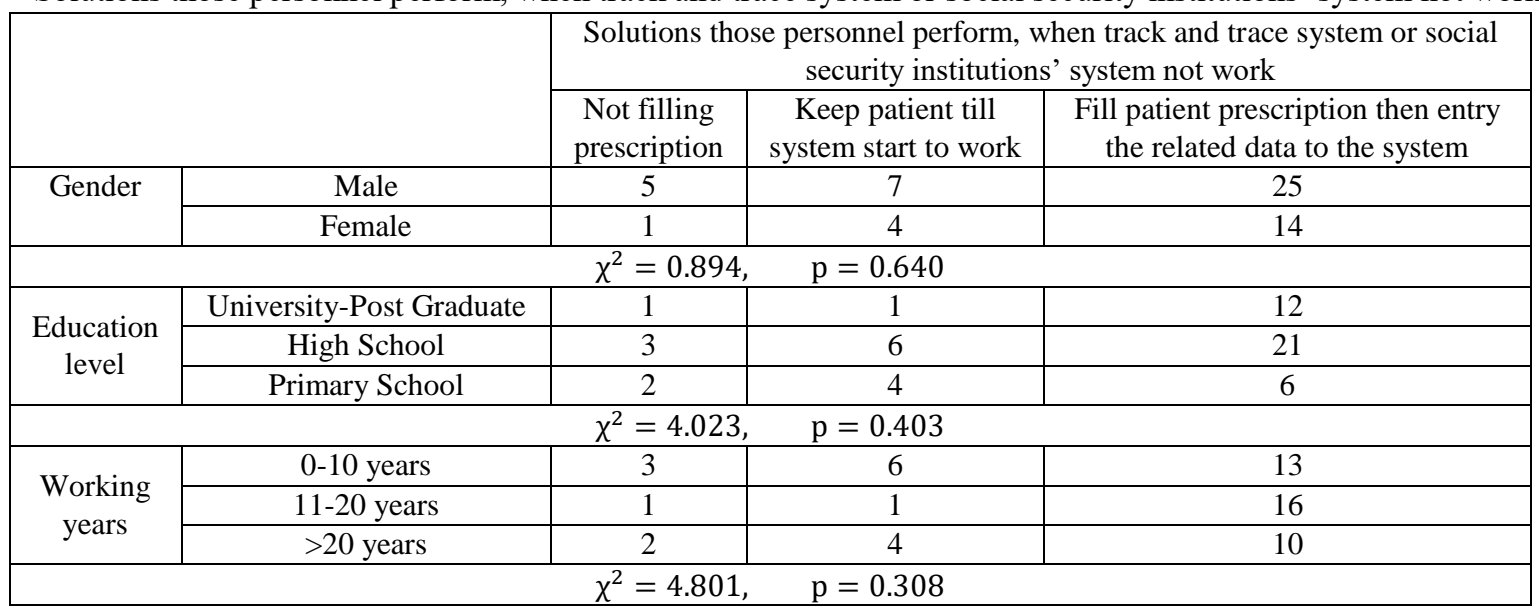

As is it can be seen from Table $\mathrm{X}$, no statistically significant relationships were found between demographics and "Solutions those personnel perform, when track and trace system or social security institutions' system not work". In this regard, it is possible to say that $\mathrm{H}_{3}$ was rejected.

In addition, for testing $\mathrm{H}_{5}$ and $\mathrm{H}_{6}$, Chi-Square tests were conducted. For this aim, relationship between solutions performed when the system was not working and "Attended any kind of seminar or training", after that relationship between solutions performed when the system was not working and attitude questions were evaluated. As a result of the study, these two hypotheses were rejected, too.

As human rights are guaranteed by the Turkish government directly, the government has conducted many reforms to centralize the management of health system. As a part of the European Union integration and compliance program, the Turkish health authorities strived to transform health care services by using the IT systems to create an European model. Substantial efforts have been made to implement a local track and trace solution that had become a requirement related to this transformation process, and Turkey becomes one of the first countries that establish this system [13]. Within this scope; pharmaceutical track and trace system can be encountered as one of the major reforms made in the Turkish healthcare system. The pharmacy personnel who is one of the most important part of pharmaceutical distribution chain and users of the PTTS should have the necessary information about the system in order to operate the system without interruption. As Yousefi and Alibabaei mentioned, skilled personnel are an important point for adapting new systems information technologies for pharmaceutical supply chain [15]. In a different point of view Bansal et al. emphasized the importance of the anti-counterfeit technologies in pharmaceutical sector and stated the necessity of education for personnel [16]. However, in the performed study, educative activities are found inadequate. On the other hand, it is surprising that the majority of the participants did not attend any training. By increasing knowledge of the PTTS users, it is thought that effectiveness of the system will also increase.

One of the main starting points of the PTTS is the protection of public health. At this point, PTTS allows singularization of each medication unit via a 2D data matrix code. In turn, the system allows related stakeholders to pursue that each unit throughout the life cycle of the medication via web services. And the system has also a closed loop to avoid any possible illegal product injection. The PTTS also provides great convenience in term of harmful drugs recall comparing to the older bureaucratic procedure, as the system prohibits the sale of the drugs in seconds even unintentionally or not. As a result of these systematic precautions, $71.43 \%$ think that the system facilitates and accelerate the recall of harmful drugs and the $87.5 \%$ of the participants of the study agreed that the system contribute to the drug safety in general. The PTTS has been activated in 2012. At the day of activation, 24,000 pharmacies entered the program at the same time, which caused the system to collapse, and in the first days of the system activation more than $80 \%$ of the drugs had errors due to the lack of registration [13]. Despite of the systemic improvements performed since 2012, it has been demonstrated by the participants that the connection breaks in the system continue at a significant level and that is the 
most important factor causing the system performance to decrease. In addition, the fact that the existing internet infrastructure has not been developed to meet the system requirements is another important reason affecting the PTTS's performance. When the system not work, different solutions are being put in practice by pharmacy personnel and as mentioned in previous section, most of them fill the prescription and then enter data to the system. This solution actually involves some risks in terms of patient and drug safety. For example, in order to enter data to the system later, the part of the package, including the DataMatrix, can be cut and taken by the pharmacy personnel. However, this can cause medicines to become unusable due to dropping or breaking. In this context, experienced personnel and personnel having higher education levels are expected to be more careful to reduce such risks. However, in contrast to this expectation, in the study, the working year and the education levels of the personnel were not found to be effective in this issue. In general, it is possible to say that there cannot be established any relationship between demographic factors such as gender, education level and the working year and the statements related knowledge, attitude, and practice of participants about PTTS. Additionally, attending any kind of seminar or training was not found related to any of the questions. This situation is thought to be endorsed due to the small number of pharmacy personnel receiving a seminar or training.

\section{Conclusions}

As a result, this study showed that Turkish PTTS is found useful especially for providing drug safety and facilitating and accelerating the recall of the drugs by community pharmacies' personnel.

The study has several interesting implications for both policy makers and pharmacists. For policy makers who want to improve the field of drug safety, educative activities about the system should be performed for increasing awareness and knowledge of this system both by community pharmacists and pharmacy personnel. From the view of pharmacists, they should encourage their staff about getting education on this issue.

To the best of the authors' knowledge, this is the first study evaluating Turkish PTTS system in various aspects. This study opens doors to a variety of perspectives for future research. By extending the questionnaire and sample size, more robust and comprehensive results will be performed in order to obtain and additionally correlations between attitude, knowledge and practices will be evaluated under a model as future researches.

\section{Conflict of interest}

The authors declare no conflict of interest.

\section{References}

1. Ludasi K, Sovány T, Laczkovich O, Hopp B, Smausz $\mathrm{T}$, Regdon G, Unique lase coding technology to fight falsified medicines. Eur J Pharm Sci., 2018; 123: 1-9.

2. World Health Organization, WHO Expert Committee on Specifications for Pharmaceutical Preparations. World Health Organ Tech Rep Ser., 2012; (970): 1-235.

3. Ilko D, Steiger C, Keller R, Holzgrabe U, Meinel L, Tamper-proof tablets for distinction between counterfeit and originator drugs through PEG coding. Eur $J$ Pharm Biopharm., 2016; 99: 1-6.

4. Dégardin K, Roggo Y, Margot P, Understanding and fighting the medicine counterfeit market. J Pharm Biomed Anal., 2014; 87: 167-175.

5. The Center For Safe Internet Pharmacies (CSIP), The Internet Pharmacy Market in 2016 Trends, Challenges, and Opportunities. https://safemedsonline.org/resource/ the-internet-pharmacy-market-in-2016-trendschallenges-and-opportunities, 2016.

6. Statista, Global online pharmacy market size 2014 and 2023. www.statista.com/.

7. Przyswa E, Guarnieri F, Counterfeiting and Cybercrime: Stakes and Challenges. Inf Soc., 2013; 29(4): 219-226.

8. Cozzella L, Simonetti C, Schirripa Spagnolo G, Drug packaging security by means of white-light speckle. Opt Lasers Eng., 2012; 50(10): 1359-1371.

9. Chambliss WG, Carroll WA, Kennedy D, Levine D, Moné MA, Ried LD, Shepherd M, Yelvigi M, Role of the pharmacist in preventing distribution of counterfeit medications. J Am Pharm Assoc., 2012; 52(2): 195-199.

10. Wajsman N, Burgos CA, Davies C, The Economic Cost of IPR Infringement In The Pharmaceutical Industry. EUIPO Report, 2016, https://euipo.europa.eu/ ohimportal/ro/web/observatory/ipr-infringementpharmaceutical-sector.

11. Musa A, Gunasekaranb A, Yusuf Y, Supply chain product visibility: Methods, systems and impacts. Exp Syst Appl., 2014; 41(1): 176-194.

12. Hsu C, Wallace WA, An industrial network flow information integration model for supply chain management and intelligent transportation. Enterp Inf Syst., 2007; 1(3): 327-351.

13. Altunkan SM, Yasemin A, Aykaç İT, Akpinar E, Turkish pharmaceuticals track \& trace system. In: $2012,7^{\text {th }}$ International Symposium on Health Informatics and Bioinformatics. April 2012; Nevsehir, Turkey, https://ieeexplore.ieee.org/document/6209037?arnu mber $=6209037$.

14. Erdoğan Ö, Sarper Erdogan M, Gunay O, Erkus S, Ulus T, Community pharmacists' perception of their clinical pharmacy service function, a study from Turkey. Farmacia, 2012; 60(5): 749-758.

15. Yousefi N, Alibabaei A. Information flow in the pharmaceutical supply chain. Iran J Pharm Res., 2015; 14(4): 1299-1303.

16. Bansal D, Malla S, Gudala K, Tiwari P, Anti-counterfeit technologies: A pharmaceutical industry perspective. Sci Pharm., 2013; 81: 1-13. 